\title{
PYTANIA FERMIEGO \\ JAKO METAFORA METODY NAUKOWEJ
}

\section{FERMI PROBLEMS AS A METAPHOR OF SCIENTIFIC METHOD}

\begin{abstract}
SUMMARY
Having to face the problem of "how many cups of water are necessary to fill the Mediterranean Sea" what solution strategy you might have to use? Try on the Internet? Try to guess formulas, values, and so on? Relying on hearsay? Urban legends? Letting go and giving up because of the apparent difficulty of the question? Yet there is a rigorous method, which have its focal points in what is rational, rigorous, creative, and intuitive, which allows you to deal with issues of this kind, leading to reliable and reasoned, albeit approximate, results. This method is based, or rather - in a sense reflects the way that the experimental science actually is using use for more than four centuries to resolve, and with great success, the problems concerning the world of nature. What is this method? This is the theme of the narrative that follows, in which the philosophy and history of science will be used in the didactic of mathematics and physics.
\end{abstract}

KEY Words: applied philosophy, philosophy of science, scientific research tradition of L. Laudan, Galileo Galilei, didactic of mathematics and physics. 
$\mathrm{Al}$ p[adre] Camp[anella]. Io stimo più il trovar un vero, benchè di cosa leggiera, che 'l disputar lungamente delle massime questioni senza conseguir verità

nissuna.

Galileusz $^{1}$

\section{O metodzie naukowej: tradycje badawcze Larry'ego Laudana i model praktyczny Galileusza}

Książka Thomasa Kuhna Struktura rewolucji naukowych jest prawdopodobnie jedną z najszerzej znanych monografii z zakresu filozofii nauki². Wielu badaczy oskarżało Kuhna o irracjonalizm, ale oskarżenia te stają się mniej zasadne, jeżeli się przyjmie, iż ta książka Kuhna jest w istocie głosem przeciw pozytywistycznej wizji racjonalności naukowej, głosem pochodzącym z wnętrza historii nauki. Podstawowymi pojęciami koncepcji Kuhna, które potem weszły do obiegowego słownictwa nie tylko filozofii nauki, są pojęcia „paradygmatu” i „rewolucji naukowej”. Thomas Kuhn jest prawdopodobnie pierwszym filozofem nauki, który podkreślał dużą „żywotność” tzw. teorii globalnych (paradygmaty) w obliczu mnożących się poważnych anomalii i który uznawał te teorie (zwane przez Laudana maxi-teoriami) za podstawowe narzędzie służące do zrozumienia i właściwego opisu rozwoju nauki.

Czym są teorie globalne albo maxi-teorie? Thomas Kuhn w swych refleksjach rozróżnia dwa typy systemów zdań lub teorii, mające różne znaczenie heurystyczne i poznawcze. Tak więc istnieje typ teorii odnoszących się do zagadnień bardzo szczegółowych, teorii używanych np. w celu dokonywania przewidywań wyników doświadczeń lub do szczegółowego wyjaśnienia przebiegu określonego zjawiska naturalnego (mini-teorie w języku Laudana). Drugi typ teorii natomiast obejmuje teorie odnoszące się do zagadnień znacznie bardziej ogólnych i w konsekwencji kontrolowalnych w znacznie mniejszym stop-

${ }^{1}$ „Do o[jca] Camp[anelli]. Wyżej sobie cenię dotarcie do prawdy, nawet w kwesti błahej, niż długie dysputy w najwyższych kwestiach, bez osiągnięcia żadnej prawdy". Uwaga zapisana ręką Galileusza na marginesie komentarze, będącego odpowiedzią na jego traktat Discorso intorno alle cose che stanno in su l'acqua o che in quella si muovono z 1612 roku (por. OG IV, 738). Krytyczna edycja dzieł Galileusza (Le Opere di Galileo Galilei: Edizione Nazionale, A. Favaro (red.), Firenze 1929-1939; przedruk) będzie tutaj cytowana poprzez skrót OG, z podaniem numeru tomu i strony.

${ }^{2}$ T. Kuhn, The Structure of Scientific Revolution, Chicago $1970^{2}$ (wyd. polskie pierwszej edycji dzieła: Struktura rewolucji naukowych, tłum. H. Ostromęcka, Warszawa 1968). Por. też T. Sierotowicz, Nauka a wiara - przestrzeń dialogu, Tarnów 1997, rozdz. 2.1. 
niu (tzw. maxi-teorie). Te dwa typy teorii różnią się nie tylko pod względem ogólności, lecz także pod względem kryteriów stosowanych w ich walutacji ${ }^{3}$.

Model rozwoju nauki zaproponowany przez Larry'ego Laudana sytuuje się w nurcie filozofii nauk wytyczonym przez Thomasa Kuhna i Imre Lakatosa. W modelu Larry’ego Laudana, który za podstawową jednostkę opisu rozwoju nauki przyjmuje tzw. tradycje badawcze ( $S c R T$ ), nauka jest interpretowana jako aktywność intelektualna i praktyczna, która w swej istocie sprowadza się do rozwiązywania problemów.

Według tego filozofa, nauki zachowanie racjonalne polega na wybieraniu tych teorii, które przyczyniają się do większego postępu naukowego. Postęp naukowy można zaś określić jako wzrastająca efektywność teorii w rozwiązywaniu problemów w danej dziedzinie badań naukowych. „Miara” tego rozwoju jest zaś następująca:

globalna efektywność danej teorii w rozwiązywaniu problemów określona jest w odniesieniu do liczby i wagi problemów empirycznych, które teoria ta rozwiązuje. Należy przy tym również uwzględnić liczbę oraz wagę anomalii i problemów koncepcyjnych, które są powodowane przez daną teorię․

Strategia stosowana w obrębie nauki sprowadza się zatem do rozwiązywania problemów. Jest to strategia określana przez Laudana mianem strategii mini-max i opiera się ona na dwóch założeniach:

(1). Rozwiązany problem, tak empiryczny, jak i koncepcyjny, jest podstawową „jednostką" rozwoju naukowego. (2). Celem nauki jest maksymalizacja znaczenia rozwiązanych problemów empirycznych i jednoczesna minimalizacja znaczenia anomalii i problemów koncepcyjnych nierozwiązanych ${ }^{5}$.

Jak widać z powyższego określenia, Laudan rozróżnia dwa zasadnicze typy problemów: empiryczne i koncepcyjne. Problemy empiryczne są: „problema-

\footnotetext{
${ }^{3}$ Por. L. Laudan, Progress and its Problems: Towards a Theory of Scientific Growth, Berkeley 1977, s. 5-6, 70-73.

${ }^{4}$ Por. tamże, s. 68. Powyższe określenie może też być odczytywane jako polemika z analitycznie/logicznie zorientowanymi podejściami do filozofii nauki. Laudan w innym miejscu cytowanego tutaj dzieła podkreśla: „the rationality and progressiveness of a theory are most closely linked - not with its confirmation or its falsification - but rather with its problem solving effectiveness" (por. tamże, s. 5). Na ten temat por. też L. Laudan, The Demise of the Demarcation Problem, w: R.S. Cohen, L. Laudan (red.), Physics, Philosophy and Psychoanalysis: Essays in Honor of Adolf Grünbaum, Dordrecht 1983, s. 111-127.

${ }^{5}$ L. Laudan, Progress and its Problems, dz. cyt., s. 66.
} 
mi pierwszej wagi i są one pytaniami podstawowymi dotyczącymi obiektów, które stanowią dziedzinę zastosowań danej nauki”'. Problemy empiryczne dzielą się na trzy kategorie: (1) problemy nierozwiązane przez żadną z teorii w danej dziedzinie; (2) problemy rozwiązane i (3) anomalie, tj. problemy nierozwiązane przez daną teorię, natomiast rozwiązane przez inne teorie z tej samej dziedziny badawczej.

Problem koncepcyjny to problem, który dotyczy samej teorii jako takiej i nie istnieje niezależnie od niej. Jeżeli zatem problemy empiryczne są problemami pierwszej wagi dotyczącymi określonej dziedziny badań, to problemy koncepcyjne rodzą się wewnątrz schematów koncepcyjnych czy tradycji badawczych, które są propozycjami rozwiązania tychże problemów empirycznych. Problemy koncepcyjne mogą być wewnętrzne (np. kiedy dotyczą niespójności logicznej danej teorii) lub zewnętrzne (kiedy są wynikiem konfliktu danej teorii bądź z inną teorią czy tradycją badawczą dobrze ugruntowaną, bądź z jakąś teorią metodologiczną, bądź też z ogólną wizją świata danej epoki).

Dokonawszy wszystkich tych rozróżnień, można wstępnie określić naukową tradycję badawczą (ScRT) jako: „zespół ogólnych założeń dotyczących obiektów i procesów zachodzących w danej dziedzinie badań oraz założeń dotyczących metod, które należy stosować celem rozwiązywania problemów oraz celem konstruowania nowych teorii w tej dziedzinie"

Innymi słowy, tradycje badawcze określają w sposób abstrakcyjny, z czego świat jest zbudowany, jakie relacje łączą istniejące w nim obiekty, jakie procesy tam zachodzą i jak należy ten świat badać, nie dostarczając przy tym żadnych konkretnych odpowiedzi na pytania i problemy szczegółowe. Tak więc tradycje badawcze nie mają funkcji wyjaśniających czy normatywnych, lecz dostarczają jedynie środków służących do rozwiązywania problemów empirycznych i koncepcyjnych. Dana tradycja badawcza „składa” się z różnych teorii (będących czasem w konflikcie między sobą), które czynią bardziej konkretną "ontologię" danej tradycji badawczej i realizują wskazania metodologiczne tejże tradycji badawczej, usiłując podać rozwiązania określonych problemów. Spośród różnych tradycji badawczych w tej samej dziedzinie badań większy sukces zyskuje ta spośród nich, która prowadzi do rozwiązania większej ilości

${ }^{6}$ Por. tamże, s. 15.

${ }^{7}$ Por. tamże, s. 81. Stwierdzenie to przypomina uwagi T. Kuhna na temat wpływu i roli paradygmatu w życiu naukowym: ,it functions by telling the scientist about the entities that nature does and does not contain and about the ways in which those entities behave" (T. Kuhn, The Structure of Scientific Revolution, dz. cyt., s. 109). 
problemów empirycznych i koncepcyjnych, oczywiście przy mniejszej ilości anomalii i problemów nierozwiązanych.

Celem ułatwienia dalszych rozważań wprowadźmy następujący, schematyczny opis $S c R T$ :

$$
S c R T \rightarrow[O ; R ; M ;\{p\} ;\{T\}]
$$

gdzie poszczególne symbole oznaczają odpowiednio: obiekty podstawowe $(O)$, relacje $(R)$ oraz metodologię $(M)$ przyjmowane w danej tradycji badawczej. Ponadto $\{T\}$ określa zbiór teorii proponowanych w ramach danej tradycji badawczej celem rozwiązanie zbioru problemów pierwszego rzędu $\{p\}$ i innych problemów koncepcyjnych występujących w danej dziedzinie refleksji ${ }^{8}$.

W tym punkcie rozważań warto przypomnieć takie oto stwierdzenie Karla Poppera dotyczące metody naukowej:

moja koncepcja metody naukowej jest następująca: metoda naukowa systematyzuje przednaukowy sposób uczenia się na podstawie błędów. Systematyzacja ta odbywa się zaś w oparciu o krytyczną dyskusję. Cała moja teoria dotycząca metody naukowej może być streszczona w stwierdzeniu, iż składa się ona z następujących trzech etapów: (1) potykamy się o jakiś problem; (2) próbujemy go rozwiązać, proponując jakąś teorię; (3) uczymy się na podstawie błędów, zwłaszcza tych uwidocznionych przez krytyczną dyskusję naszych wysiłków zmierzających do rozwiązania danego problemu. Lub, by ująć rzecz jeszcze krócej, można to wszystko wyrazić w trzech słowach: problemy-teorie-krytyka. Jestem przekonany, iż w tych trzech słowach streszcza się cała metoda postępowania nauk racjonalnych' ${ }^{9}$.

${ }^{8}$ Należy podkreślić, iż pisząc tutaj o nauce, Laudan nie ma na myśli tylko fizyki, lecz raczej wiele nauk obejmujących różne dziedziny ludzkiego poznania. Opis ten przypomina Evandra Agazziego ujęcie nauki oparte na analogii. Według Agazziego, pojęcie nauki stosuje się analogicznie do matematyki, fizyki, biologii, chemii czy psychologii. Dyskurs naukowy w każdej dziedzinie badań odnosi się do wyraźnie określonego zbioru przedmiotów i nie obejmuje całości rzeczywistości. Z punktu widzenia metodologicznego dyskurs naukowy charakteryzuje się rygorem i obiektywnością. Dodać należy, że konkretne znaczenie tych terminów ulega zmianie przy przechodzeniu od jednej dziedziny nauki do drugiej, jednakże to właśnie one analogicznie określają naukowość danej dziedziny poznania. Por. E. Agazzi, Analogicità del concetto di scienza. Il problema del rigore e dell'oggettività nelle scienze umane, w: V. Possenti (red.), Epistemologia e scienze umane, Milano 1979, s. 57-76, E. Agazzi, L’analogicità del concetto di scienza, „Nuova Secondaria", 2 (1988), s. 1. Podobne podejście do nauki proponuje John Dupré: The Disorder of Things: Metaphysical Foundations of the Disunity of Science, Cambridge (MA) 1993.

${ }^{9}$ K. Popper Objective Knowledge, Oxford 1972 (wyd. polskie: Wiedza obiektywna, tłum. A. Chmielewski, Warszawa 1994), s. 287-288. 
Odwołując się do terminów nieco ogólniejszych, model metody naukowej w ujęciu Poppera może być ujęty, jak następuje. Punktem wyjścia nauki jest określona sytuacja problemowa $\left(P_{1}\right)$. Następnie są proponowane różne hipotezy i teorie (TT) będące próbami rozwiązania wyjściowej sytuacji problemowej. Owe teorie są w następnym kroku poddawane surowej krytyce $(E E)$. Początkowa sytuacja problemowa uzyskuje swoje rozwiązanie i zwykle prowadzi do dalszych sytuacji problemowych $\left(P_{2}\right)$ wymagających rozwiązania. Model rozwoju nauki według Poppera jest zatem następujący:

$$
P_{1} \rightarrow T T \rightarrow E E \rightarrow P_{2}
$$

Powyższa, wstępna rekonstrukcja definicji $S c R T$ wymaga jednak istotnego uzupełnienia. Otóż Laudan, chcąc zilustrować swą koncepcję, podaje następujące przykłady $S c R T$ : empiryzm i nominalizm w filozofii, darwinizm i teoria kwantów w nauce, mechanicyzm i witalizm w fizjologii itp. Laudan, komentując te różne tradycje badawcze, stwierdza, iż łączącym je czynnikiem są „określone metafizyczne i metodologiczne zaangażowania, które wzięte jako całość definiują daną tradycję oraz odróżniają ją od innych tradycji”" ${ }^{10}$.

Zważywszy na to doprecyzowanie Laudana, pełna definicja $S c R T$ winna uwzględnić również owe metafizyczne (ontologiczne) i metodologiczne wybory, a może lepiej ów metafizyczny i metodologiczny „dekalog”, które określa daną $S c R T$. Powracając teraz do głównego nurtu rozważań i wprowadzając symbol I na oznaczenie dopiero co wspomnianego "dekalogu” ScRT (zaangażowania metafizyczne i metodologiczne $S c R T$ ), otrzymuje się następującą symboliczną definicję tradycji badawczej:

$$
S c R T \rightarrow[I ; O ; R ; M ;\{T\} ;\{\mathrm{p}\}]
$$

Rzecz jasna niemal wszystkie elementy określające $S c R T$ (za wyjątkiem składowej I) mogą ewoluować z czasem, prowadząc do coraz to innych realizacji tej samej tradycji badawczej. W tych okolicznościach można mówić o zmianach wewnętrznych danej $S c R T$, w której metody, teorie i cele poznawcze (tj. problemy do rozwiązania) podlegają ciągłym zmianom. Wypada podkreślić, iż składowa $I$ tradycji badawczej jest czynnikiem unifikującym różne realizacje tej samej $S c R T$, tak w aspekcie diachronicznym (identyczność $S c R T$ w czasie, pomimo zachodzących zmian wewnętrznych), jak i w aspekcie synchronicznym.

${ }^{10}$ L. Laudan, Progress and its Problems, dz. cyt., s. 79. Na następnej stronie Laudan pisze: "a research tradition is thus a set of ontological and methodological «do's» and «don'ts»". 
Mówiąc o jedności w aspekcie synchronicznym, mam na myśli tę okoliczność, iż składowe $O, R, M$ i $\{T\}$ danej $S c R T$ są w istocie konkretną realizacją danej tradycji badawczej, realizacją służącą rozwiązaniu określonych problemów empirycznych czy koncepcyjnych w oparciu o składową I danej tradycji badawczej. Pozwala to uważać ScRT za rodzaj struktury pojęciowej, skonstruowanej w określonym celu, a nie za przypadkowy zbiór idei, teorii czy metod.

Zmiany zachodzące w danej $S c R T$, zmierzające do rozwiązania określonego problemu podstawowego (czy też koncepcyjnego), mogą być interpretowane - w innej nieco perspektywie - jako zmiany prowadzące do coraz to większej koherencji wewnątrz danej tradycji badawczej. Taka interpretacja jest możliwa na gruncie metodologicznego modelu nauki interpretującego naukę jako lekturę księgi natury ${ }^{11}$. W modelu tym stwierdza się, iż proces wyjaśniania naukowego to ciągły wysiłek zmierzający do coraz to większej koherencji, mającej charakteryzować teoretyczny system nauki, włączając w to i obserwacje. Interpretując każdą nową obserwację, każdy nowy problem podstawowy lub koncepcyjny jako nowy fragment tekstu można utrzymywać, iż te nowe znaki i linijki, „przeczytane”, „wyczytane”, „doczytane”, „odczytane” czy też „sczytane", na kartach księgi natury, albo i między jej już odczytanymi zdaniami, uzyskują sens jedynie w perspektywie hipotezy dotyczącej tego, co się wydarza w całym dotąd poznanym opowiadaniu (hipoteza ta może być utożsamiona z ScRT). W przypadku rozwoju tradycji naukowej, podobnie jak to ma miejsce w odniesieniu do hermeneutyki tekstu, dostrzec można ten sam schemat interpretacyjny, charakteryzujący się dążeniem do coraz to większej koherencji pomiędzy rozumieniami „lokalnym” i „globalnym” interpretowanego tekstu. Wysiłki te mają wiele wspólnego z próbami zrozumienia czytanej książki, w których to próbach zrozumienia określonej, niewielkiej części tekstu zależy od zrozumienia całości przeczytanego dotąd tekstu. Chodzi tutaj o swoistą konfrontację pomiędzy rozumieniem fragmentu książki i rozumieniem całości, której jakby regułą nadrzędna jest właśnie koherencja tych dwóch rozu-

${ }^{11}$ Tego rodzaju teoretyzacja poznania naukowego została zaproponowana przez P. Kosso. Jego model, jak zresztą każdy inny metodologiczny model nauki, ma granice swego zastosowania, których to granic sam autor nie omieszkuje podkreślić: „należy zdawać sobie sprawę z faktu, iż analogia pomiędzy nauką i lekturą ma sens jedynie na poziomie metodologicznym. Nawet jeżeli w nauce i lekturze metody usprawiedliwiania czy interpretacji okażą się podobne, nie znaczy to bynajmniej, iż konkluzja ta pozostaje słuszna w odniesieniu do ich przedmiotów. W szczególności zaś powyższa analogia metodologiczna nie chce sugerować, jakoby natura miała swego autora" (P. Kosso, Leggere il libro della natura. Introduzione alla filosofia della scien$z a$, Bologna 1995, s. 12). 
mień: lokalnego i globalnego ${ }^{12}$. Można zatem utrzymywać, iż „proces rozwoju nauki oferuje ciągle rozwijający się obraz świata, obraz, którego koherencja jest podtrzymywana lub powiększana, dzięki ciągłej konfrontacji pomiędzy teoriami i obserwacjami”'13.

Ujęcia Laudana i Kosso zdają się szczególnie dobrze przystawać do tego, co można określić jako metodę albo sposób formułowania i rozwiązywania problemów, które znaleźć można w pismach Galileusza, zwanego też Pizańczykiem ${ }^{14}$.

Jak wiadomo, Galileusz napisał w Wadze probierczej (Il Saggiatore) następujące, szeroko cytowane słowa:

filozofia zawarta jest w tej przeogromnej księdze, którą ciągle mamy otwartą przed oczami (nazywam tę księgę wszechświatem), jednakże nie można jej pojąć, jeśli wpierw nie pozna się języka, nie pozna się liter, w których została ona napisana. A księga ta została napisana w języku matematyki, i jej literami są trójkąty, koła i inne figury geometryczne; bez tych środków niemożliwe jest dla człowieka zrozumienie słowa w niej zapisanego; bez nich udziałem człowieka jest próżne błąkanie się po ciemnym labiryncie ${ }^{15}$.

Cytowane słowa autora Sidereus Nuncius nie są tylko i wyłącznie wyrazem głębokiej historycznie, teologicznie i filozoficznie intuicji, lecz także streszczają - takie jest moje przekonanie - procedurę poznawczą stosowaną przez samego Pizańczyka. Procedura ta daje się ująć w terminach $S c R T$, jak to zostanie niżej zilustrowane na przykładzie pytania dotyczącego położenia plam słonecznych (w tym przypadku jeden z elementów $\{\mathrm{p}\}$ ScRT Galileusza). Kwestia została szczegółowo opisana, zinterpretowana i rozwiązana w ramach ScRT Pizańczyka, proponowanej $\mathrm{w}$ dziele Istoria e dimostrazioni intorno alle macchie solari e loro accidenti $i^{16}$.

Powyższe dzieło powstało w okresie intensywnej aktywności obserwacyjnej Galileusza, kiedy to za pomocą ulepszonego przez siebie teleskopu dokonał on wielu odkryć na sferze niebieskiej. Z jednej strony, obserwacje te uczyniły

${ }^{12}$ Por. tamże, s. 161.

${ }^{13}$ Por. tamże, s. 158.

${ }^{14} \mathrm{Na}$ temat Galileusza por. np. A. Fantoli, Galileusz, tłum. T. Sierotowicz, Tarnów 2002, T. Sierotowicz, Galileusz, WAM, Kraków 2003 (drugie wydanie dostępne jest w profilu autora na stronie Academia.edu), T. Sierotowicz, O położeniu plam słonecznych, Tarnów 2013, a także J. Kierul, Galileusz, Warszawa 2012 oraz cytowaną tam literaturę.

${ }^{15}$ OG VI, 232 (por. Galileusz, Waga probiercza, tłum. T. Sierotowicz, Tarnów 2009, s. 55).

${ }^{16}$ Rzym 1613 (OG V, s. 25-239). Szczegóły w: T. Sierotowicz, O położeniu plam słonecznych, dz. cyt., zwłaszcza s. 153-208. 
z Galileusza osobę sławną i znaną w całej Europie, z drugiej zaś - otworzyły przed oczami ówczesnych ludzi nowy świat mgławic, gwiazd, planet i satelitów, a także i plam dostrzegalnych na powierzchni Słońca. To właśnie kwestia położenia tych plama stanie się przedmiotem dysputy z uczonym jezuitą, ojcem Christopherem Scheinerem. Pizańczyk, opierając się na zaproponowanej przez siebie geometryczno-kinematycznej metodzie obserwacyjnej, określonej przez niego samego jako metoda praktyczna (il metodo pratico - OG V, s. 121), starał się bronić tezy, iż plamy te znajdują się na powierzchni Słońca.

Ściśle rzecz biorąc, powyższy argument został zaproponowany wcześniej przez Scheinera, jednakże jego formalizacja i efektywne zastosowanie są dziełem Galileusza, który powołuje się na ten argument w innym niż Scheiner kontekście filozoficznym (w sensie składników I; $O ; R$ danej $S c R T)^{17}$. Ujmując kwestię syntetycznie, można powiedzieć, iż Galileusz, w opozycji do Scheinera, interpretował plamy słoneczne jako zjawisko zachodzące na powierzchni Słońca lub bardzo blisko tej powierzchni tak, że biorą one udział w obrotowym ruchu Gwiazdy Dziennej. Scheiner natomiast twierdził, iż plamy to cienie rzucane na powierzchnię Słońca przez planety przechodzące przez tarczę słoneczną w okresie obserwacji plam przez obserwatora ziemskiego. Planety te miały się poruszać z prędkością kątową równą prędkości kątowej obrotu Słońca i znajdować się w pewnej odległości od samego Słońca.

Oto podstawowe elementy rozwiązania zaproponowanego przez Galileusza. Jako się rzekło, chodzi tutaj o rodzaj kinematyczno-geometrycznego argumentu ściśle opartego na obserwacjach ( $M$ tradycji badawczej Galileusza). W ostatecznym rozrachunku odwołuje się on do zmian obserwowanej odległości dwóch plam słonecznych, znajdujących się na tym samym równoleżniku słonecznym, w miarę ich przemieszczania się od brzegów do centrum tarczy Słońca (należy wybrać takie plamy, które w ich ruchu przechodzą przez sam środek tarczy słonecznej albo też w równej odległości od niego, po tej samej stronie równika słonecznego). Pizańczyk założył też, że cokolwiek powoduje powstanie plam, porusza się po lub bardzo blisko sferycznej powierzchni

${ }^{17}$ Galileusz akceptuje system Kopernika, neguje tezę o niezmienności niebios oraz podziale wszechświata na świat pod- i nadksiężycowy, co prowadzi np. do odrzucenia przekonania o niezmienności Słońca. Kiedy się bierze pod uwagę składniki $I, O$ i $R$ tradycji badawczych, ScRT Pizańczyka jest zasadniczo różna od tradycji Scheinera i może być określona jako kopernikańska - istnieje przebogata literatura dotycząca zagadnienia rewolucji kopernikańskiej tamtego okresu - pars pro toto: T. Kuhn, Przewrót Kopernikański. Astronomia planetarna w dziejach myśli, tłum. S. Amsterdamski, Warszawa 1966. 
Słońca, która unosi plamy ze sobą, i że plamy poza ruchem wynikającym z ruchu powierzchni nie wykonują żadnego innego ruchu własnego.

Wpierw Galileusz konstruuje to, co można określić jako model praktyczny badanego zjawiska. Wyobraźmy sobie linię łączącą oko obserwatora ziemskiego i środek sfery Słońca (elementy składnika $\{T\}$ Galileuszowej ScRT). Weźmy następnie pod uwagę płaszczyznę prostopadłą do tej linii, przechodzącą przez środek Słońca i oś jego obrotu (płaszczyzna obserwacji). Przecięcie tej płaszczyzny z kulą słoneczną definiuje brzeg obserwowanej tarczy słonecznej. Na tle tej tarczy obserwator ziemski dostrzega poruszające się plamy słoneczne. Ich obrazy powstają w tym miejscu tarczy słonecznej, w którym linia równoległa do linii łączącej oko obserwatora oraz środek Słońca i przechodząca przez plamę (albo przez ciało powodujące powstanie plamy, nieznajdujące się na powierzchni Słońca) przecina prostopadle płaszczyznę obserwacji. Należy podkreślić, iż Galileusz uważa, że promienie słoneczne trafiające do oka obserwatora są równoległe, co jest naturalnie uproszczeniem, jednakże uzasadnionym znikomością średnicy Słońca w porównaniu z odległością pomiędzy Słońcem i ziemskim obserwatorem. Galileusz zauważył, że odległość między dwiema plamami poruszającymi się w wyżej opisany sposób ulega perspektywicznemu skróceniu (efekt projekcji na płaszczyznę obserwacji) zależnie od kąta nachylenia odcinka łączącego plamy w odniesieniu do płaszczyzny obserwacji oraz od ich odległości od powierzchni Słońca. Kiedy jednak odcinek ten stanie się równoległy do płaszczyzny obserwacji, wówczas długość tego odcinka i długość jego prostopadłego rzutu na płaszczyznę obserwacji będą sobie równe. Zachodzi to w sytuacji, kiedy linia łącząca oko obserwatora ze środkiem Słońca pokryje się ze środkiem odcinka łączącego plamy, przy założeniu, że plamy poruszają się po równoleżniku przechodzącym przez środek tarczy słonecznej.

Oczywiście nie zawsze nadarza się możliwość dokonania tego rodzaju obserwacji. Galileuszowi dopisało szczęście, albowiem obserwacje dokonane w dniach 1-5 lipca 1613 zdają się odpowiadać wyżej opisanym warunkom, pozwalając tym samym na rozstrzygnięcie sporu między dwiema hipotezami dotyczącymi położenia plam, poprzez bezpośredni pomiar długości odcinków definiowanych przez położenia plam słonecznych na skraju i na środku tarczy słonecznej. Porównując tym sposobem proponowany model $\mathrm{z}$ wynikami obserwacji, Pizańczyk konkluduje, stwierdzając, iż obserwacje z tych dni przedstawiają sytuację, „która nie mogłaby mieć miejsca, jeśliby plamy poruszały się po okręgu 
dowolnie odległym od powierzchni Słońca" ${ }^{18}$. Jest to błyskotliwy argument pozwalający na bezpośrednie rozstrzygnięcie postawionego problemu poprzez odniesienie do obserwacji, a dokładniej - poprzez dokonanie pomiaru w oparciu o praktyczny (geometryczny) model analizowanej sytuacji problemowej.

W następnym kroku, po rozwiązanie problemu położenia plam słonecznych w oparciu o model praktyczny, Galileusz powołuje się także na inne obserwacje, przewidując na podstawie obliczeń ich wyniki w sytuacji, kiedy plamy znajdują się na Słońcu, uciekając się w tych przypadkach do rachunków opartych na geometrycznych aspektach wyżej proponowanego modelu praktycznego. Podkreśla przy tym znaczenie zgodności uzyskiwanych wyników. Używał do określenia tej zgodności terminu connession de’veri, mając na uwadze harmonię dowodów i argumentów, z których w przypadku konkretnego $\left\{p_{\text {es }}\right\}$ rozważanego przez Pizańczyka wynika, iż „wszystkie te argumenty tak są ze sobą powiązane (la connession déveri), że w konsekwencji wynika $\mathrm{z}$ nich położenie plam na powierzchni Słońca oraz to, że plamy te są unoszone przez obrotowy ruch Słońca. Nie bardzo bowiem wiadomo, z jakich powodów plamy, jeśliby się znajdowały daleko od powierzchni Słońca, miałyby się poruszać wraz z jego ruchem obrotowym" 19 .

W przypadku metody stosowanej przez Galileusza dwa momenty zasługują na szczególną uwagę. Po pierwsze, znaczenie modelu geometrycznego, który znajduje zastosowanie do opisu konkretnej sytuacji obserwacyjnej i służy jako punkt wyjścia do zaproponowania odpowiedniego rozwiązania. Model ten nie ma charakteru li-tylko ilustracji zagadnienia, jest bowiem jednocześnie narzędziem pomiarowym i heurystycznym, pozwalającym na rozwiązanie problemu. Jednakże model - i to jest drugi z wyżej wymienionych aspektów - został skonstruowany w oparciu o pewne upraszczające założenia, jak dla przykładu to, dotyczące równoległości promieni światła, co z kolei pozwalało na dalszą matematyzację zjawisk i na dokonywanie obliczeń dotyczących określonych aspektów zachowania się plam słonecznych.

Uproszczenia tego rodzaju staną się niezwykle istotne w rozważaniach Galileusza, chociażby w dziedzinie kinematyki, czego przykłady znaleźć można $\mathrm{w}$ wielu miejscach jego rozprawy Discorsi e dimostrazioni matematiche intorno a due nuove scienze $e^{20}$. Tam Galileusz, posługując się wyobraźnią, rozumuje, ide-

${ }^{18}$ OG V, 122.

${ }^{19}$ OG V, 120.

${ }^{20} \mathrm{G}$. Galilei, Rozmowy i dowodzenia matematyczne w zakresie dwóch nowych umiejętności, tłum. i red., F. K[ucharzewski], Warszawa 1930. 
alizując kształty i powierzchnie, abstrahując od ich nieregularności niemających zasadniczego wpływu na przebieg obserwowanego zjawiska ${ }^{21}$. Uproszczenia te są sztuką, i to sztuką niełatwą, nadto bardzo ryzykowną, zwłaszcza jeśli uzna się za drugorzędny czynnik odgrywający centralną rolę w przebiegu takiego czy innego zjawiska. Sam Galileusz popełniał błędy w tej sztuce, dla przykładu w przypadku teorii przypływów morza. W jego pojęciu pływy mórz były wynikiem sumowania się ruchów obrotowego i obiegowego Ziemi. Tak czyniąc, zaniedbał jednak zasadniczy element, który powinien był wziąć pod uwagę, to jest fakt, iż okres czasu między dwoma następującymi po sobie przypływami nie wynosi dokładnie 12 godzin, lecz 12 godzin i 24 minuty ${ }^{22}$.

Dla podsumowania tej z konieczności krótkiej prezentacji koncepcji tradycji badawczych Larry'ego Laudana oraz jej aplikacji w przypadku badań Galileusza, chciałbym uwypuklić dwa aspekty metody naukowej, szczególnie dobrze widoczne w traktacie Pizańczyka o plamach słonecznych. Galileusz, pragnąc rozwiązać interesujące go problemy, konstruuje $S c R T$. Problemy wyznaczające jego $S c R T$ nie dotyczą „najwyższych systemów”, lecz są to zagadnienia o zgoła mniejszym znaczeniu, bardzo szczegółowe kwestie. Proponując stosowne rozwiązania, Galileusz dokonuje wielu uproszczeń. Jest to konieczne, jeśli chce się dobrze określić i sformułować zagadnienie oraz wyodrębnić czynniki mające centralne znaczenie w jego przebiegu. Mówiąc krótko, realizuje to, co Lorella Congiunti streszcza w wyrażeniu „wykorzenić przeszkody ze strony przyrody"23. Sadzę, że już powierzchowna lektury podręczników z zakresu historii nauki pokazuje, jak bardzo tego rodzaju operacja jest konieczna, jeśli chce się zaproponować efektywne rozwiązania problemów naukowych ${ }^{24}$.

${ }^{21}$ Dla przykładu na początku czwartego dnia Rozmów i dowodzeń Galileusz pisze: „mobile quoddam super planum horizontale proiectum mente concipio omni secluso impedimento" (OG VIII, 268; por. tamże, s. 176).

${ }^{22}$ G. Grimvall, Facciamo due conti, Bari 2013, s. 186-188. Jeśli chodzi o Galileusza teorię przypływów por. np. L. Russo, Flussi e riflussi. Indagine sullorigine di una teoria scientifica, Milano 2003 oraz T. Sierotowicz, „Rozprawa o przypływach i odpływach morza” Galileusza. Tłumaczenie rozprawy, „Zagadnienia Filozoficzne w Nauce” 55 (2014), s. 129-165 i cytowaną tam literaturę.

23 „Diffalcare gli impedimenti della natura” (L. Congiunti, Soggetto del sapere e scienze moderne, Milano 2005, s. 77-94).

${ }^{24}$ Sądzę, iż można zaryzykować tezę, według której tego rodzaju postępowanie poznawcze nie jest właściwe tylko i wyłącznie dla metody naukowej, lecz jest stosowane w każdej sytuacji, w której pojawia się jakiś problem i chce się stwierdzić, jak się rzeczy mają. Podejmuję tę tezę w przygotowywanych obecnie esejach: Analisi matematica per i poeti ovvero Il grafico di una funzione e il Monsieur Poirot cioè paradigma indiziario nella didattica di matematica oraz La 
Ale to nie wszystko. Rozwiązując „mniej znaczące” kwestie, Galileusz odwołuje się do modelu geometrycznego będącego wiernym odwzorowaniem zjawiska. Jest to odwzorowanie izomorficzne badanej rzeczywistości w tym sensie, że dzięki konstrukcji geometrycznej, formule algebraicznej czy funkcji matematycznej, powstaje model zawierający tę samą ilość elementów, co badane zjawisko, zachowujący przy tym strukturę relacji istniejących pomiędzy tymi elementami ${ }^{25}$. Zważywszy okoliczność, iż w modelowaniu zjawisk przyrodniczych zdecydowanie przeważają środki matematyczne, słuszna zdaje się teza Clavelina, iż zasadnicza cecha racjonalności Galileusza wyraża się w formułowaniu problemów przyrodniczych, tak jak formułuje się problemy matematyczne ${ }^{26}$. Uproszczenia i modele matematyczne: $\mathrm{w}$ moim pojęciu takie właśnie są dwie cechy charakteryzujące metodę Galileusza; cechy, które w ramach jego $S c R T$ umożliwiły przejście od świata mniej-więcej do świata precyzji, jak to celnie ujął Alexander Koyrè27.

Podsumowując: odwołanie się do modelu matematycznego oraz dokonanie określonych uproszczeń umożliwia sformułowanie danego problemu w taki sposób, iż staje się on częścią (lub nawet ją definiuje) naukowej tradycji badawczej, wchodząc tym samym w zakres takiej czy innej dziedziny nauki. To, co zostało wyżej napisane na temat $S c R T$ oraz na temat metody Galileusza, jest zobrazowane na rysunku 1.

\section{Pytania Fermiego i dydaktyka fizyki oraz matematyki}

Konstrukcja modelu geometrycznego badanego zjawiska przyrodniczego, posługując się przy tym takimi czy innymi uproszczeniami celem udzielenia odpowiedzi na postawione pytanie, jest procedurą normalną w ramach róż-

poltrona e i fatti ovvero studio sul metodo del Monsieur Poirot. Idę w tych esejach śladem moich poprzednich opracować dotyczących paradygmatu poszlakowego C. Ginzburga: T. Sierotowicz, Przekład tekstu Carla Ginzburga: Tropy. Korzenie paradygmatu poszlakowego, „Zagadnienia Filozoficzne w Nauce" 39 (2006), s. 3-65 oraz Poszlakowy paradygmat kosmologii, w: R. Janusz, S. Wszołek (red.), Wyzwania racjonalności. Księdzu Michałowi Hellerowi - współpracownicy i uczniowie, Kraków 2006, s. 340-353.

${ }^{25}$ J.R. Brown, Philosophy of Mathematics. An Introduction to the World of Proofs and Pictures, London-New York 2008², s. 39.

${ }^{26}$ M. Clavelin, The Natural Philosophy of Galileo. Essay on the Origins and Formation of Classical Mechanics, Cambridge (Massachusetts)-London 1974, s. 454.

${ }^{27}$ A. Koyrè, Dal mondo del pressappoco all'universo della precisione, w: tegoż, Dal mondo del pressappoco all'universo della precisione. Tecniche, strumenti e filosofia dal mondo classico alla rivoluzione scientifica, Torino 1982, s. 89-111. 


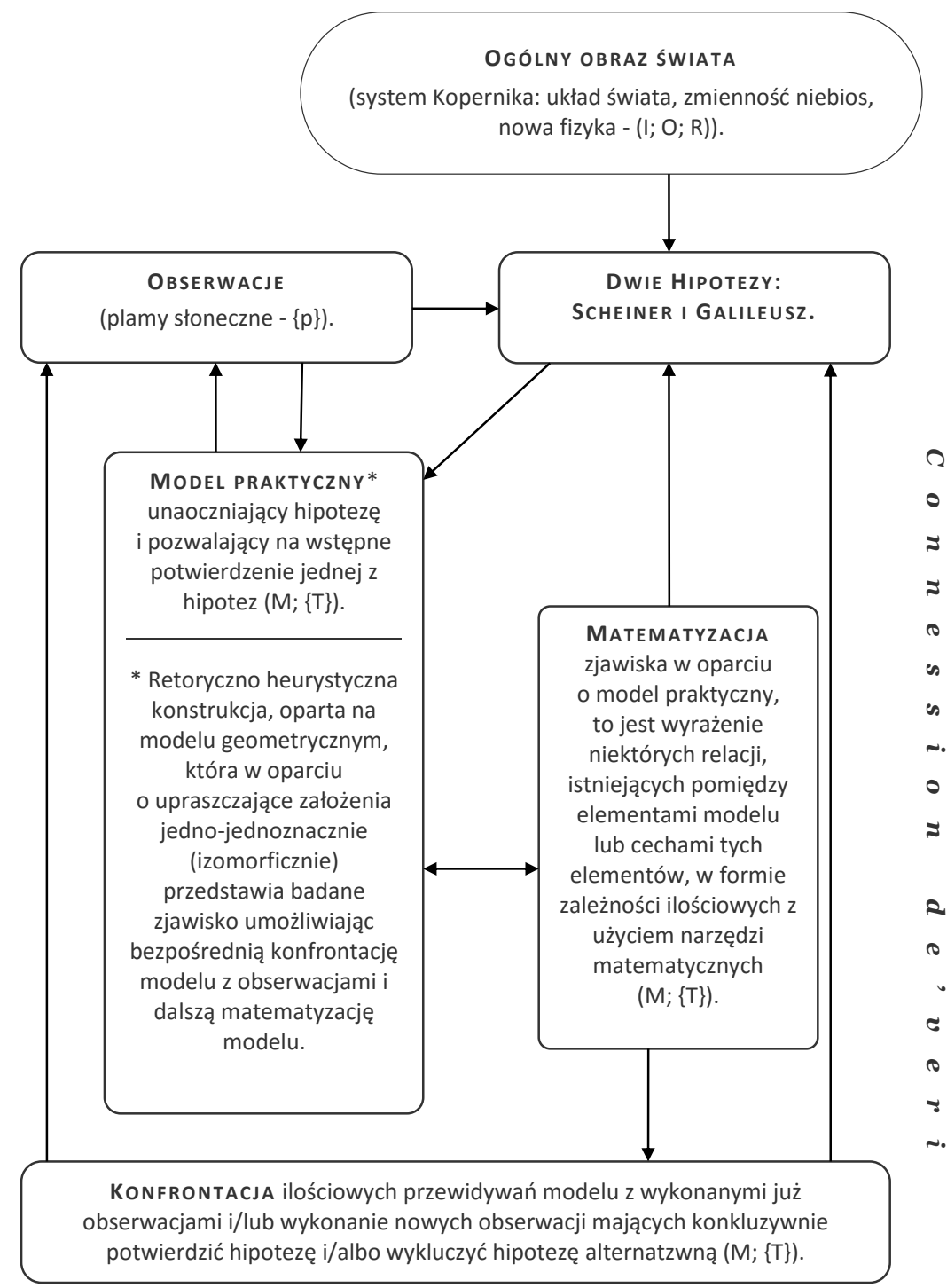

Rys. 1. Tradycja badawcza Galileusza - kwestia położenia plam słonecznych.

nych ScRT, np. w ramach tej, zaproponowanej przez Galileusza. Więcej: tego rodzaju procedury są uważane za najwyższy przejaw racjonalności naukowej. Nic zatem dziwnego, iż znajomość procedur ułatwiających budowanie geometrycznych i matematycznych modeli zjawisk przyrodniczych, w połączeniu ze 
sztuką aproksymacji należą do podstawowych punktów curriculum szkolnego fizyka. Dlatego też ucząc fizyki, a także i matematyki rozumianej jako narzędzie pozwalające na odczytywanie księgi przyrody, nie można pominąć dopiero co wspomnianych narzędzi poznawczych.

Göran Grimvall, pisząc na te tematy w swym interesującym, choć bynajmniej niełatwym opracowaniu Facciamo due conti, zauważa, iż w praktyce naukowej skoncentrowanie się na podstawowych aspektach danego zjawiska oznacza w istocie rzeczy konstrukcję jego modelu. Naturalnie taki model nie „przedstawia całej rzeczywistości”, lecz tylko te jej aspekty, które są ważne z punktu widzenia prowadzonych analiz i stawianych pytań ${ }^{28}$. W konsekwencji Grimvall podkreśla: „ważnym aspektem edukacji naukowej w szkołach wyższych jest nauczanie sztuki upraszczania złożonych problemów, co pozwala na skupienie się na ich fundamentalnych cechach"29.

Idąc śladem wskazówek Grimvalla, wkracza się w zakres tego, co określa się czasem mianem dydaktyki opartej na problemach. Krisnel Nosari wyjaśnia, iż termin ten „odnosi się do strategii nauczania opartej na przedstawianiu studentom złożonych problemów paradygmatycznych, zakorzenionych w realnym świecie albo bardzo do takich sytuacji zbliżonych, których konstrukcja nie przewiduje jednej tylko, ściśle określonej wartości numerycznej, będącej rozwiązaniem postawionej kwestii" ${ }^{30}$.

W tak rozumianej dydaktyce szczególnie przydatne zdają się tzw. pytania Fermiego ${ }^{31}$. Wybitny fizyk włoski znany był z werwy twórczej, która przejawiała się m.in. w formułowaniu pytań charakteryzujących się tym, iż celem udzielenia odpowiedzi należało sformułować wiele upraszczających hipotez umożliwiających „określenie rzędu wielkości liczby stanowiącej odpowiedź”. Istnieje

${ }^{28}$ G. Grimvall, Facciamo due conti, dz. cyt., s. 246; por. tamże s. 157-173.

${ }^{29}$ Por. tamże, s. 245.

${ }^{30}$ Por. dostępny w sieci materiał dotyczący wykładu K. Nosariego, Didattica per proble$m i$, www.fermimn.gov.it/formazione/KRISNEL/DIDATTICA\%20PER\%20\%20PROBLEMI.pdf (dostęp 18 czerwca 2015).

${ }^{31}$ Jeśli chodzi o dydaktykę fizyki i matematyki opierającą się na pytaniach Fermiego oraz o jej ogólnoedukacyjne aspekty por. np. następujące opracowania i cytowaną tam literaturę: M.K. Dirks, D.T.R. Edge, Problem Solving: Enrico Fermi and the Bull Moose, „Vector” 40 (1999), s. 25-28, B. Sriraman, L. Knott, The Mathematics of Estimation: Possibilities for Interdisciplinary Pedagogy and Social Consciousness, „Interchange” 40 (2009), s. 205-223, J. Bergman Ärlebäck, On the Use of Realistic Fermi Problems for Introducing Mathematical Modelling in School, „The Montana Mathematics Enthusiast" 6 (2009), s. 331-364, L. Albarracín, N. Gorgorió, Inconceivable Magnitude Estimation Problems: an Opportunity to Introduce Modelling in Secondary School, „ZDM - Journal of Mathematical Modelling and Application” 7 (2012), s. 20-33. 
wiele przykładów tego rodzaju pytań łatwo dostępnych w wielu monografiach i w sieci ${ }^{32}$, jednakże pozostają paradygmatyczne pytania Fermiego dotyczące liczby stroicieli fortepianów mieszkających w Chicago oraz to domagające się oszacowanie rzędu wielkości energii wyzwolonej w próbnym wybuchu bomby atomowej na podstawie analizy ruchu niewielkiego kawałeczka papieru.

Pełniejszą definicję zaproponował Bergman Ärlebäck:

pytania Fermiego (...) są to niestandardowe pytania otwarte wymagające (...) przyjęcia wiele upraszczających założeń dotyczących sytuacji będącej przedmiotem pytania oraz licznych przybliżeń co do wartości numerycznych związanych z tą sytuacją, zanim przystąpi się do wykonania względnie prostych obliczeń prowadzących do szukanej odpowiedzi ${ }^{33}$.

Podkreślając wagę pytań Fermiego w dydaktyce, Andrew Robinson dodaje:

ażeby odpowiedzieć na pytanie Fermiego, należy zaproponować model fizyczny zjawiska, poddać analizie stosowne prawa fizyki, określić czynniki limitujące badane zjawisko, jak np. warunki początkowe, śledzić z uwagą powstawanie uproszczonego modelu tak, by nie oddalił się zanadto od rzeczywistości. Dopiero wtedy będzie można zastosować tak uproszczony model do sytuacji będącej przedmiotem pytania. Tego rodzaju ćwiczenie wymaga wiedzy zawodowego fizyka; wiedzy, który fizycy zdobywają dopiero w czasie studiów uniwersyteckich i która - jak wynika z wielu badań statystycznych - najczęściej nie jest przedmiotem nauczania na poziomie licealnymi ${ }^{34}$.

Inny autor zaznacza: „pytania Fermiego są (...) doskonałym narzędziem umożliwiającym ćwiczenie sztuki rozumowania, sprowadzanie problemów pozornie złożonych do serii prostych procedur poprzez formułowanie koniecznych do tego hipotez. Pytania te umożliwiają też zrozumienie znaczenia rachunkowego oszacowania wyniku". Następnie, komentując strategie konieczne do odpowiedzi na tego rodzaju pytania dodaje, iż chodzi tutaj o kwestie „któ-

${ }^{32}$ Por. np. G. Grimvall, Facciamo due conti, dz. cyt., L. Weinstein, J.A. Adam, Più o meno quanto?, Bologna 2009, Wydział Fizyki Uniwersytetu w Maryland The Fermi Problems Site, http://www.physics.umd.edu/perg/fermi/fermi.htm (dostęp 15 października 2015) oraz Science Olympics, http://www.physics.uwo.ca/science_olympics/events/puzzles/fermi_questions.html (dostęp 15 października 2015).

${ }^{33}$ J. Bergman Ärlebäck, On the Use of Realistic Fermi Problems, dz. cyt., s. 331-332.

${ }^{34}$ A.W. Robinson, Don't just Stand There - Teach Fermi Problems!, „Physics Education” 43 (2008), s. 83. Por. także A. Van Heuvelen, Learning to Think Like a Physicist, „American Journal of Physics" 59 (1991), s. 888-897. 
rych rozwiązanie nie zawsze daje się wyrazić dokładną wartością tak, że wystarczające jest określenie rzędu wielkości szukanego rozwiązania" ${ }^{35}$. Oczywiście po uzyskaniu przybliżonego rozwiązania, zależnie od sytuacji, rozwiązanie może być poprawiane, uściślane, podane $\mathrm{z}$ większą dokładnością $\mathrm{i}$ porównane $\mathrm{z}$ całością dostępnej wiedzy, a także z innymi oszacowaniami uzyskanymi na drodze innych przybliżeń. Tym sposobem otwiera się furtka „dydaktyczna”, otwierająca drogę do dyskursu na temat krytycznej analizy wyników.

Odpowiadając na pytania Fermiego, postępuje się zwykle tak, jak fizyk, który proponuje geometryczny lub algebraiczny model badanego zjawiska, przyjmując przy tym, iż wzór, funkcja mogą być uważane przynajmniej do pewnego stopnia za model relacji charakteryzujących dane zjawisko. Krótko rzecz ujmując, fizyk (uczeń) rozwiązujący problem Fermiego proponuje izomorficzny, jedno-jednoznaczny model przedstawiający badane zjawisko. W tym sensie model analogicznie przedstawia analizowany fragment rzeczywistości. Jednakże wprowadzenie modelu oznacza też uproszczenie badanej sytuacji, pozostawiając w centrum uwagi tylko to, co istotne dla przebiegu opisywanego zjawiska/sytuacji. Dopiero w następnym kroku poszukuje się informacji koniecznych do oszacowania poszukiwanej wartości lub co najmniej do realistycznej oceny jej rzędu wielkości. Otwiera się tutaj następna furtka „dydaktyczna”, pozwalająca na podjęcie kwestii krytycznego poszukiwania niezbędnych informacji, np. w Internecie ${ }^{36}$.

Jak widać, ma się tutaj do czynienia ze strategią, która mimo prostoty rozważanej sytuacji wymaga zastosowania podstawowych procedur właściwych metodzie naukowej. Dlatego też pytania Fermiego pozwalają na zapoznanie

${ }^{35}$ T. Maccacaro, Strategie per domande difficili, http://www.scienzainrete.it/contenuto/ articolo/strategie-domande-difficili (dostęp 18 czerwca 2015).

${ }^{36}$ Metodyczne udzielanie odpowiedzi na pytania Fermiego (por. rys. 2) realizuje wiele aspektów myślenia krytycznego, strategii poznawczej zajmującej poczesne miejsce we współczesnych doktrynach pedagogicznych. Klasyczną definicję podał Robert Ennis: „critical thinking (...) means reasonable reflective thinking focused on deciding what to believe or do" (por. stronę http://www.criticalthinking.net/ i cytowaną tam literature - dostęp 13 maja 2016). Chociaż uważna lektura klasycznych opracowań na ten temat bynajmniej tego nie sugeruje, w moim pojęciu myślenie krytyczne nie jest ani najbardziej podstawową, ani tym mniej jedyną strategią poznawczą. Naturalnie jej rola i znaczenie w dziedzinie nauk przyrodniczych nie ulega dyskusji. Jednakże nawet i tutaj stosowną definicję należałoby uzupełnione o konstatację analogicznego charakteru strategii, jak to było wcześniej podkreślone w odniesieniu do pojęcia nauki, a szerzej tradycji badawczych. Proponowałbym zatem następującą wersję definicji: „critical thinking (...) means reasonable reflective thinking focused on deciding what to believe or do in the specific context of knowledge or belief". 
się z metodą naukową i na ćwiczenie się w jej użyciu. Powyższe uwagi na temat pytań Fermiego oraz strategii poszukiwania odpowiedzi zostały przedstawione na rysunku 2.

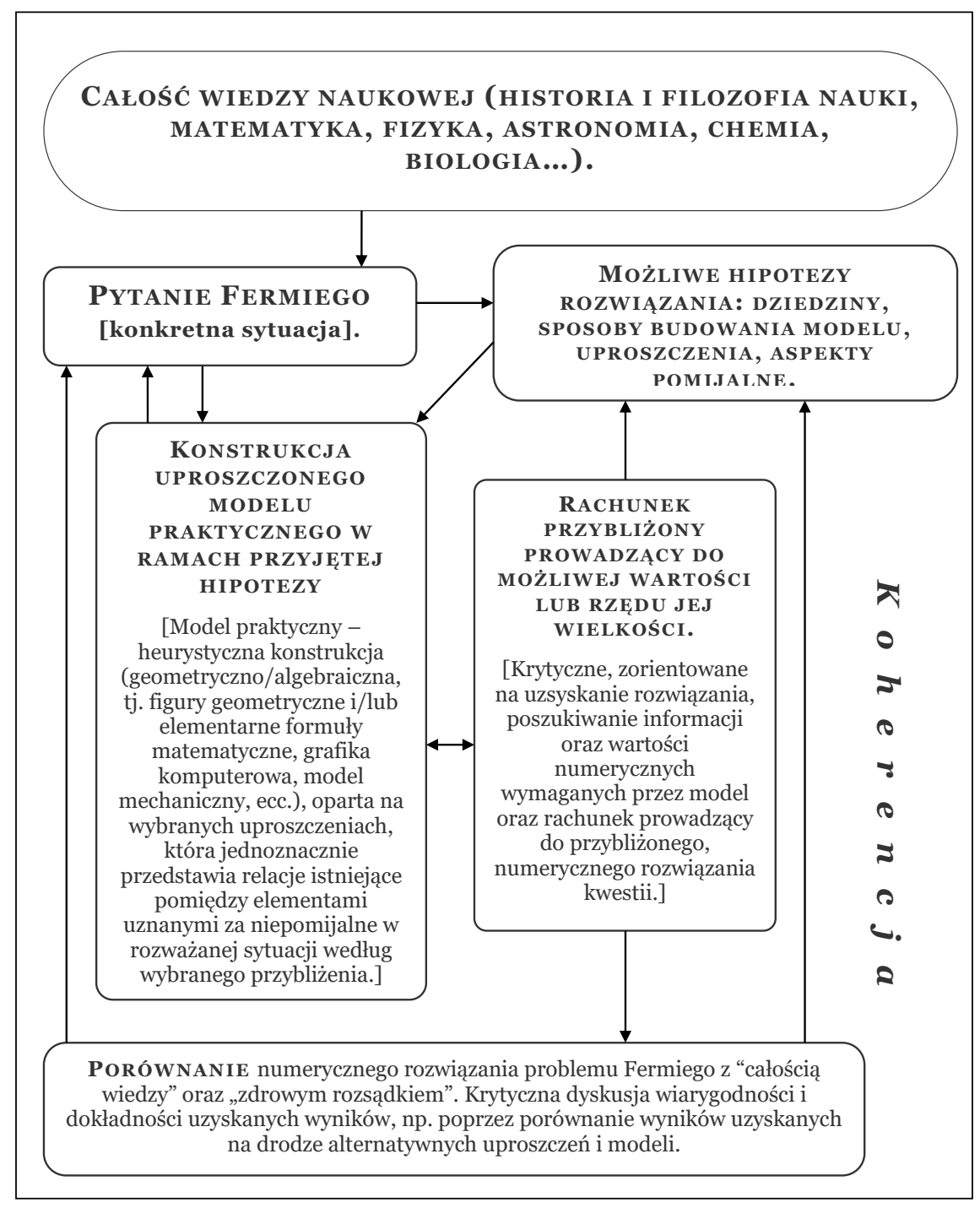

Rys. 2. Pytanie Fermiego i odpowiedzi na to pytanie - próba syntezy. 


\section{Podsumowanie:}

\section{Pytanie Fermiego jako traktat metodologiczny w miniaturze}

Enrico Fermi utrzymywał, iż potrafi wiarygodnie oszacować rząd wielkości czegokolwiek, byle tylko owe „cokolwiek” było wyrażalne za pomocą liczby. Dodać trzeba, iż każda odpowiedź na pytanie Fermiego to jedna z możliwych odpowiedzi w tym sensie, że zwykle dopuszczalne są alternatywne podejścia do tego samego pytania ${ }^{37}$. Widać to na rysunkach 1 i 2 . O ile bowiem pierwszy schemat miał prowadzić do rozstrzygnięcia tego, co retorzy nazywają dylematem dialektycznym, o tyle drugi w przypadku tego samego problemu może być kilkakrotnie zastosowany, odwołując się do różnych, możliwych w danej sytuacji hipotez. Pominąwszy tę różnicę, schematy przedstawione na rysunkach 1 i 2 wykazują daleko idące podobieństwa. I nic w tym dziwnego, zważywszy podejście przyjęte w niniejszym eseju. Warto może jednak zatrzymać się na chwilę nad tym podobieństwem, odwołując się do bardziej filozoficznego języka.

Na pierwszym miejscu należy wskazać na już podkreślane znaczenie modeli w praktyce naukowej. Widać to wyraźnie na rysunku 1 , syntetyzującym metodę stosowaną przez Galileusza. Jego metoda praktyczna jest właściwie próbą zaproponowania geometrycznego modelu opisywanego zjawiska, który to model wymyka się próbom jednoznacznej klasyfikacji. Istotnie, opierając się na kategoriach Maxa Blacka, stwierdzić należy, iż model ten jednoczy w sobie tak cechy modelu w skali, jak i cechy modelu matematycznego lub/i teoretycznego ${ }^{38}$. Z kolei Mary Hesse w swej klasycznej monografii dotyczącej modeli i analogii w praktyce naukowej podkreśla, iż teorie naukowe właśnie modelom zawdzięczają możliwość dokonywania przewidywań (predictive pover of mo$d e l s)^{39}$. Ten aspekt jest łatwo zauważalny w metodzie praktycznej Galileusza stosowanej przez niego samego do odpowiedzi na pytanie o położenie plam słonecznych. Tak w przypadku podejścia Galileusza, jak i w przypadku pytań Fermiego siła przewidywania stosowanego modelu matematyczno/geometrycznego sprowadza się w istocie rzeczy do praktycznego (numerycznego) rozwiązania postawionego zagadnienia.

${ }^{37}$ M.K. Dirks, D.T.R. Edge, Problem Solving, dz. cyt., s. 25.

${ }^{38}$ Por. S. Gimbel (red.), Exploring the Scientific Method: Cases and Questions, Chicago 2011, s. 256-264.

${ }^{39}$ „A model, for me, is any system, whether buildable, picturable, imaginable, or none of these, which has the characteristic of making a theory predictive" (M. Hesse, Models and Analogies in Science, Notre Dame 1966, s. 19; por. tamże s. 129). 
Tyle narzędzia pojęciowe filozofii nauki. Jednakże z punktu widzenia dydaktyki szczególnie ważna zdaje się nie tylko rola matematyki jako narzędzia pozwalającego na zaproponowanie modelu badanego zjawiska i ośrodkowe znaczenie tego ostatniego w całości stosowanej procedury, lecz także podobieństwa dostrzegalne między schematami przedstawionymi na rysunkach 1 i 2. Celem opisania tego podobieństwa przywołać należy centralną rolę metafory w języku filozoficznym. W dyskusjach dotyczących tego tematu szczególnie wiele uwagi poświęcono poznawczej roli metafory, czyli innymi słowy jej roli heurystycznej. Paul Ricoeur, pisząc na temat metafor, podkreślał właściwą metaforom zdolność tworzenia znaczenia, to jest „wywarzanie nowego znaczenia za pośrednictwem środków językowych"40. Jest to jeden z powodów, dla których metafora jest czasem określana jako „poemat w miniaturze”, co ma wyrażać jej fundamentalną rolę w konstrukcji wizji świata. W konsekwencji mówi się czasem o „metaforze żywej” ${ }^{41}$. Więcej - Monroe Beardsley, który zaproponował opis metafory jako „poemat w miniaturze”, jednoznacznie stwierdza, iż „sposób wyjaśniania proponowany przez metaforę jest modelem wszelkiego wyjaśniania" ${ }^{42}$.

Metafora zatem, w kontekście dyskursu czy też narracji literackiej albo filozoficznej, odznacza się zdolnością do „tworzenia” znaczenia. W kontekście dydaktyki, te same mechanizmy językowe mogą ułatwić komunikowanie nowego znaczenie tym, którzy uczniami będąc, pierwszy raz wkraczają w niezmierzony wszechświat ludzkiego poznania. Każdej dziedziny ludzkiego poznania: matematyki, fizyki, astronomii, historii nauki, literatury itp. W tej perspektywie pytania Fermiego mogą być uważane za dydaktyczną metaforę metody naukowej, swoisty poemat w miniaturze, opowiadający uczniowi zasadnicze elementy tejże metody. Jest to metafora, która w ramach krótkiej, matematycznie i fizycznie zorientowanej narracji pozwala uczniowi na dokonanie odkrycia nowego znaczenia, to jest pozwala na wypracowanie obrazu zasad metody naukowej, sposobu jej funkcjonowania, procedur uzasadniania, potwierdzania itd. ${ }^{43}$ Krótko rzecz ujmując, pozwala na odkrycie idei, na któ-

\footnotetext{
${ }^{40}$ P. Ricoeur, Riflessione fatta, Milano 1998, s. 58.

${ }^{41}$ Por. odpowiednio: M.C. Beardsley, Aesthetics, Problems in the Philosophy of Criticism, Indianapolis 1981, s. 144, P. Ricoeur, Interpretation Theory: Discourse and the Surplus of Meaning, Fort Worth 1976, s. 52 oraz Ch. Perelman, Il dominio retorico, Torino 1981, s. 134.

${ }^{42}$ M.C. Beardsley, Aesthetics, dz. cyt., s. 144.

${ }^{43}$ Por. A. Sfard, Reification as the Birth of a Metaphor, „For the Learning of Mathematics” 14 (1994), s. 44-55.
} 
rych opiera się współczesne przyrodoznawstwo. I nie tylko odkrycie, lecz także - tak to ujmijmy - dotknięcie metody poprzez jej praktyczne zastosowanie w konkretnej sytuacji poznawczej.

Tadeusz Sierotowicz (ur. 1960, Nowy Sącz), dr hab. Zajmuje się filozofią nauki, zwłaszcza $w$ aspekcie jej relacji z teologią, literaturą oraz dydaktyką matematyki i fizyki. Autor publikacji dotyczących Galileusza i tłumacz jego dzieł na język polski. Współpracuje z Centrum Kopernika Badań Interdyscyplinarnych w Krakowie oraz z Istituto di Scienze Religiose w Bolzano (Włochy). Opublikował m.in. Nauka a wiara - przestrzeń dialogu, Tarnów 1997 (poszerzona i poprawiona wersja polska książki La casa nel mondo interpretato; wyd. II poprawione w profilu: Academia.edu); Od metodycznej polemiki do polemiki metodologicznej. Impresje z lektury 'Wagi probierczej' Galileusza wraz z antologia, Tarnów 2008 (wyd. II, poprawione i zmienione, zatytułowane Aut Ceasar aut nihil, jest dostępne pod adresem internetowym: https:// isr.academia.edu/TadeuszSierotowicz/Books); O położeniu plam słonecznych, Tarnòw 2013 oraz tłumaczenie dzieła Galileusza Waga probiercza, KrakówTarnów 2009. Obecnie przygotowuje włoską edycję Filozofii dramatu ks. prof. J. Tischnera oraz artykuł: Fenomenologia del metodo investigativo-parte seconda. Monsieur Poirot e l'esperienza «Ah, ah», „Nuova Secondaria”. 
Aniwersytet Papieski

Tf: Ja! Jana Pawła II

(ii w Krakowie 